\title{
Tirotoksikoz nedenli erektil disfonksiyon üzerine sildenafil etkisinin histopatolojik olarak değerlendirilmesi
}

\section{Histopathological evaluation of sildenafil effect on erectile dysfunction caused by thyrotoxicosis}

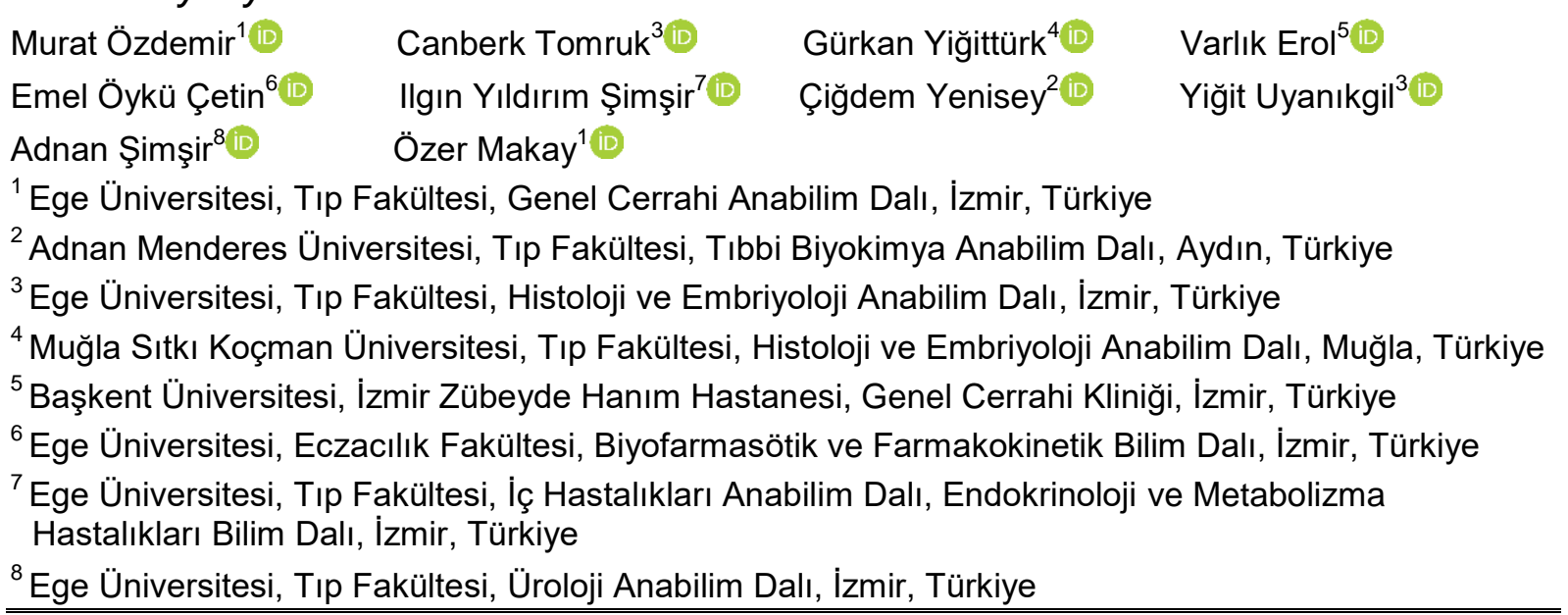

Öz

Amaç: Tirotoksikoz, periferik kan ve dokulardaki tiroit hormonu fazlalığından kaynaklı tüm klinik tabloları karşılayan bir çatı terimdir. Tirotoksikoz tablosu birçok organ ve metabolik süreci olumsuz yönde etkilemektedir. Bunlardan biri de erkek üreme sistemidir. Bu deneysel çalışmada tirotoksikoz nedenli erektil disfonksiyonda sildenafil tedavisinin disfonksiyonu önleyebilme etkisinin histopatolojik olarak değerlendirilmesi amaçlanmıştır.

Gereç ve Yöntem: Her biri 8 sıçandan oluşan 4 çalışma grubu oluşturuldu. Bu deneysel gruplar; Kontrol, Tirotoksikoz (Deney grubu), Tirotoksikoz + sildenafil uygulanan grup (Tedavi grubu) ve Tirotoksikoz oluşturulan + sildenafil çözücü solüsyon uygulanan grup (plasebo) grubu şeklindedir. Tirotoksikoz grubu erkek sıçanlara $0,2 \mathrm{mg} / \mathrm{kg} / \mathrm{gün}$ dozunda ile 7 gün boyunca L-tiroksin enjekte edildi. Tedavi grubuna ise L- tiroksin uygulamasını takiben $10 \mathrm{mg} / \mathrm{kg} / \mathrm{gün}$ dozda sildenafil, 24 gün boyunca intraperitoneal olarak uygulandı. Deneysel model tamamlanınca penis dokusu histokimyasal ve immünohistokimyasal incelemeler için \%4'lük paraformaldehit içine alındı. Rutin immünohistokimyasal takip ve boyamalar yapılarak tüm örnekler ışık mikroskobunda değerlendirildi.

Bulgular: Deney grubuna ait deneklerde kavernöz boşluklarda dejenerasyon, daralma ve endotel hücrelerinde kayıp olduğu saptandı. Fibroelastik bağ doku ve düz kas dağılımı açısından tirotoksikoza maruz kalan sıçanlarda elastik lifler ve düz kaslarda belirgin azalma, kollajen liflerde ise artış olduğu saptandı. Tedavi grubunda tunica albuginea, corpus cavernosum, venöz sinüsler, kavernozal trabeküler düz kas ve ince fibröz bağ doku normal histolojik yapıya yakın olduğu görüldü. Kavernöz cisimlerin çapları istatistiksel olarak anlamlı bulundu $(p<0,001)$. Kavernöz yapılarda fibrozis, dejenerasyon ve daralma sonuçlarında benzer farklılıklar gözlenmiştir.

\footnotetext{
Sorumlu yazar: Murat Özdemir

Ege Üniversitesi, Tıp Fakültesi, Genel Cerrahi Anabilim Dalı,

İzmir, Türkiye

E-posta: muratozdemir.md@gmail.com

Başvuru Tarihi: 08.05.2020 Kabul Tarihi: 28.06.2020
} 
İkili analizlere göre kontrol- tedavi ve deney- plasebo grupları arasındaki farklılıklar istatistiksel olarak anlamlı değilken, diğer tüm ikili farklııklar anlamlı bulunmuştur $(p<0,05)$. Periferik sinir dejenerasyonu açısından ise sadece kontrol grubunun deney ve plasebo grubu ile olan farklılıkları anlamlı bulundu $(p<0,05)$.

Sonuç: Deneysel tirotoksikoz modelinin penil kavernöz dokuda histolojik hasara neden olduğu tespit edilmiştir. Ekzojen sildenafil uygulamasının histopatolojik olarak dejeneratif etkileri azalttığı saptanmıştır.

Anahtar Sözcükler: Deneysel tirotoksikoz, penil doku, histopatoloji.

\begin{abstract}
Aim: Thyrotoxicosis is a term that meets all clinical pictures caused by excessive thyroid hormone in peripheral blood and tissues. The thyrotoxicosis table negatively affects many organs and metabolic processes. One of them is the male reproductive system. In this experimental study, the histopathological evaluation of the effect of preventing dysfunction of sildenafil treatment in erectile dysfunction due to thyrotoxicosis is aimed.
\end{abstract}

Materials and Methods: Four study groups were formed, each consisting of 8 rats. These experimental groups: The control group, Thyrotoxicosis (Experimental) group, Thyrotoxicosis+ sildenafil applied group (Treatment group) and Thyrotoxicosis+ sildenafil solvent applied group (Placebo). Male rats in the thyrotoxicosis group were injected with a dose of $0.2 \mathrm{mg} / \mathrm{kg} /$ day for 7 days with L-thyroxine. Following the application of L-thyroxine to the treatment group, sildenafil at a dose of $10 \mathrm{mg} / \mathrm{kg} /$ day was administered intraperitoneally for 24 days. When the experimental model was completed, 4\% paraformaldehyde was taken for histochemical and immunohistochemical examinations. Routine immunohistochemical monitoring and staining were done, and all samples were evaluated under a light microscope.

Results: In the subjects belonging to the experimental group, degeneration in the cavernous spaces, narrowing and loss of endothelial cells were determined. In the rats exposed to thyrotoxicosis in terms of fibroelastic connective tissue and smooth muscle distribution, there was a significant decrease in elastic fibers and smooth muscles and an increase in collagen fibers. In the treatment group, tunica albuginea, corpus cavernosum, venous sinuses, cavernosal trabecular smooth muscle and thin fibrous connective tissue were found to be close to normal histological structure. Diameters of cavernous bodies were found statistically significant $(p<0.001)$. Similar differences were observed in fibrosis, degeneration, and contraction results in cavernous structures. According to the bilateral analysis, while the differences between the control-treatment and experimental-placebo groups were not statistically significant, all other binary differences were found significant $(p<0.05)$. In terms of peripheral nerve degeneration, only the control group's differences with the experimental and placebo groups were found to be significant $(p<0.05)$.

Conclusion: It has been determined that the experimental model of thyrotoxicosis caused histological damage in penile cavernosae. It has been provided that exogenous sildenafil application reduces histopathological degenerative effects.

Keywords: Experimental thyrotoxicosis, penile tissue, histopathology.

\section{Giriş}

Hipertiroidi, tiroit bezindeki sentez artışına bağlı tiroit hormon fazlalığı anlamına gelirken tirotoksikoz terimi periferik kan ve dokulardaki tiroit hormonu fazlalığından kaynaklı tüm klinik tabloları karşılayan çatı bir terimdir. Bu duruma hipertiroidi tablosunun eşlik edip etmemesine göre iki ana grupta incelenebilir $(1,2)$. Tirotoksikoz nedenleri arasında yer alan Graves hastalığı, toksik multinodüler guatr, toksik adenom ve ovaryan teratom dokusu içerisinde anormal tiroit dokusunun bulunduğu struma ovarii gibi patolojilerde hipertiroidizm eşlik ederken; tiroit foliküler hücrelerinin inflamatuvar süreçlerle yıkıma uğradığı tiroiditler ve eksojen tiroit hormonu alınması gibi durumlarda hipertiroidizm görülmemektedir $(2,3)$.

Tirotoksikoz tablosu birçok organ ve metabolik süreci olumsuz yönde etkiler, bunlardan biri de erkek üreme sistemidir ve cinsel isteksizlik, prematür ejakülasyon, erektil disfonksiyon gibi klinik sonuçların yanı sıra sperm sayı ve 
motilitesini bozduğunu gösteren çalışmalar da mevcuttur (4-6). Bu klinik tablolardan biri olan erektil disfonksiyonun hastaların fiziksel ve psikolojik sağlığı üzerine olumsuz etkileri mevcuttur. Tedavisinde öncelikli olarak fosfodiesteraz tip 5 (PDE-5) inhibitörleri kullanılır; bu amaçla kullanılan ilk ilaç olan sildenafil oral olarak etkilidir. PDE-5 inhibitörleri yapısal olarak cGMP'ye benzerler ve yarışmalı inhibisyon mekanizması ile PDE-5'e bağlanıp cGMP'nin yıkımını önleyerek penil ereksiyonun oluşmasını sağlar $(7,8)$.

Bu bilgiler ışığında planlanan deneysel çalışmada tirotoksikoz nedenli erektil disfonksiyonda sildenafil tedavisinin disfonksiyonu önleyebilme etkisinin histopatolojik olarak değerlendirilmesi amaçlanmıştır.

\section{Gereç ve Yöntem}

\section{Deneysel Tasarım}

$\mathrm{Bu}$ çalışma için Adnan Menderes Üniversitesi Hayvan Deneyleri Yerel Etik Kurulundan onay alınmıştır. Çalışma süresince hayvan hakları ile ilgili olarak National Institute of Health $(\mathrm{NIH})$ 'in belirlediği ölçütler (Principles of Laboratory Animal Care) esas alınmıştır. Çalışmanın deneysel kısmı Adnan Menderes Üniversitesi Tıp Fakültesi Deney Hayvanları biriminde, histolojik analizleri Ege Üniversitesi Tıp Fakültesi Histoloji ve Embriyoloji Anabilim Dalı'nda yapılmıştır.

Adnan Menderes Üniversitesi Tıp Fakültesi Deney Hayvanları Yetiştirme Merkezi'nden temin edilen, seksüel olgunluğa erişmiş, ağırlıkları 200$240 \mathrm{gr}$ arasında değişen, 28 adet Wistar albino erkek sıçan kullanılmıştır. Çalışma süresince hayvanlar, kenarları sert plastik ve üstünde çelik Izgara bulunan $(19 \times 12 \times 12 \mathrm{~cm})$ kafeslerde tekli gruplar halinde barındırılmış, standart laboratuvar diyetiyle beslenmiş ve su alımları serbest bırakılmıştır. Oda sıcaklığı $24 \pm 1^{\circ} \mathrm{C}$ 'de tutulmuş, deney süresince uygun şekilde ışık almaları sağlanan bir ortamda, 12 saat aydınlık/ karanlık siklusu içinde ve günde bir kez temizlenen kafeslerde barındırılmışlardır. Kontrol ve bakımları aralıksız ve düzenli olarak yapılmıştır.

\section{Deney Grupları}

Grup 1: Herhangi bir işlem görmeyen grup (Kontrol) $(\mathrm{n}=7)$

Grup 2: Tirotoksikoz oluşturulan grup (Deney) $(n=7)$
Grup 3: Tirotoksikoz oluşturulan + sildenafil uygulanan grup (Tedavi) $(n=7)$

Grup 4: Tirotoksikoz oluşturulan + sildenafil çözücü solüsyon uygulanan grup (plasebo) $(n=7)$

Sıçanlara, L-tiroksin (Sigma T-2376) 7 gün boyunca $0,2 \mathrm{mg} / \mathrm{kg} / \mathrm{gün}$ dozunda intraperitoneal (i.p) uygulanarak tirotoksikoz oluşturuldu (Grup 2, 3, 4). Tedavi grubuna (Grup 3), 7 gün süre ile Ltiroksin uygulaması yapılmıştır. Deneysel tirotoksikoz modeli oluşturulmuş olarak kabul edilen bu gruptaki sıçanlara daha sonra 24 gün boyunca i.p olarak sildenafil (Deva AŞ, İstanbul) $10 \mathrm{mg} / \mathrm{kg} / \mathrm{gün}$ dozda uygulandı (9). Plasebo grubuna (Grup 4) ise 7 gün boyunca 0,2 $\mathrm{mg} / \mathrm{kg} / \mathrm{gün}$ dozunda intraperitoneal (i.p.) uygulanarak tirotoksikoz oluşturulup 24 gün boyunca i.p. olarak serum fizyolojik uygulaması yapıldı.

\section{Histokimyasal boyama yöntemi}

Denekler sakrifiye edildikten sonra histopatolojik inceleme için penil doku örnekleri bir kısmı \%4'lük paraformaldehit solüsyonuna alındı. Dokular kademeli bir alkol serisinde (\%80-95$100)$ dehidrate edildi ve parafine gömüldü. Parafin doku bloklarından ışık mikroskobu için kesitler mikrotomda (Leica RM 2145; Leica Camera AG, Wetzlar, Almanya) $5 \mu \mathrm{m}$ kalınlığında alındı. Histokimyasal olarak Hematoksilen\&Eozin (H\&E) ve Masson trikrom (MT) ile boyama yapıldı.

\section{Immünohistokimyasal boyama yöntemi}

Işık mikroskobik takibi yapılan ve kesitleri alınan örnekler, ksilol içinde deparafinizasyon ve distile su ile rehidrasyondan sonra, 15 dakika boyunca sitrat tamponu (\%0,3'lük sitrat, $\mathrm{pH} 6.0$ ) içinde tutuldu. Fosfat tamponlu salin (PBS) içinde yıkadıktan sonra, spesifik olmayan immünglobulin transferini engellemek için 30 dakika boyunca normal at serumuna maruz bırakıldılar, ardından 1:200 oranındaki anti-iNOS (BS- 2072R, Bioss Inc, USA), anti-eNOS (BS0163R, Bioss Inc, USA) ve anti-VEGF (BS1957R, Bioss Inc, USA) bir gece nemli bir ortamda $4^{\circ} \mathrm{C}$ 'de inkübasyonu sağlandı. Endojen peroksidaz aktivitesi, $\mathrm{H}_{2} \mathrm{O}_{2}$ (\%3'lük, 10 dakika boyunca) ile bloke edildi. Kesitler daha sonra oda sıcaklığında 30 dakika boyunca sekonder antikor (SensiTek HRP Anti-Polyvalent Lab Pack Goat Polyclonal, 1: 200, ScyTek Laboratories, USA) ile inkübe edildi ve 30 dakika süreyle Horseradish peroksidaz konjuge streptavidin ile yıkandı. Tüm kesitler 3,3'-diaminobenzidin tetrahidroklorür 
(DAB)/ $\mathrm{H}_{2} \mathrm{O}_{2}$ ile görünür hale getirildi. Kesitler Mayer's hematoksilen ile karşıt boyandı, artan alkol serisinde (2 dakika \%95 ve 2 dakika \%100) dehidrate edildi ve entellan ile kapama yapıldı. Histokimyasal ve immunohistokimyasal olarak boyanmış preparatlar Olympus BX-51 mikroskobu (Olympus Corp. Tokyo) ile incelendi ve Olympus C-5050 dijital kamera (Olympus Corp.) ile fotoğraflandı.

\section{İstatistiksel Yöntem}

Görüntüler Image-Pro Express v. 4.5.1.3 yazılımında (Media Cybernetics Inc., Cambridge, UK) analiz edildi. Tüm dijital kantifikasyonlar (Image-Pro Plus, v. 6.0, Media Cybernetics Inc.) ve değerlendirmeler deneye kör iki histolog tarafından yapıldı (Şekil-1). Her gruba ait farklı 10 preparattan randomize 25 adet kavernöz cismin çaplarının ölçümü yapıldı. Kavernöz yapılardaki fibrozis, dejenerasyon, daralma ve periferik sinir dejenerasyonlarını değerlendirmek için 0'dan 3'e ( 0 =yok; $1=$ hafif derece; $2=$ orta derece; $3=$ yüksek derece) bir skala oluşturularak histopatolojik skorlama yapıldı.

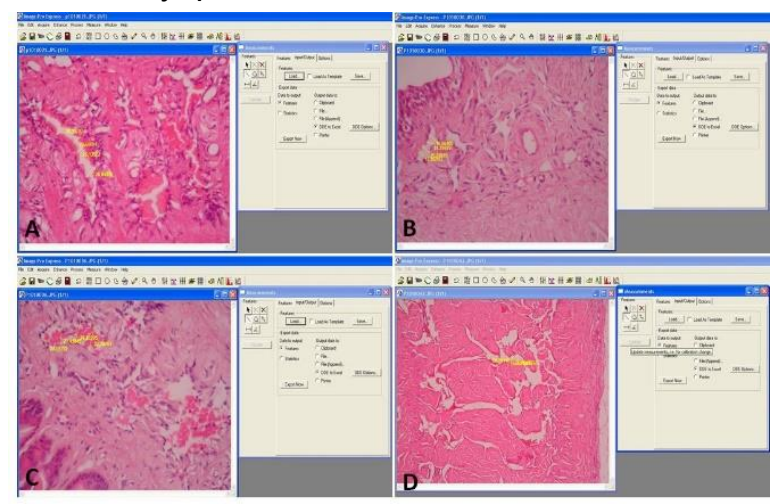

Şekil-1. Her gruba ait örneklerin Image-Pro Express v. 4.5.1.3 yazılımında (Media Cybernetics Inc., Cambridge, UK) ile değerlendirilmesi. A. Kontrol grubu. B. Deney grubu. C. Tedavi grubu. D. Plasebo grubu.

İstatistiksel değerlendirmeler IBM SPSS Statistics for Windows, Version 25.0.(IBM Corp. Released 2017, Armonk, NY) gerçekleştirildi. Kavernöz damar çapları, Tek Yönlü Varyans analizi ile karşılaştıııldı. Varyans homojenliği Levene Testi ile kontrol edilip post hoc yöntem olarak Bonferroni Testi kullanılmıştır. Histopatolojik değerlendirmeler için dört grup arası farklılık Kruskal Wallis Testi ile incelendikten sonra, gruplar arası ikili analizlerde post hoc yöntem olarak Dunn testi kullanılmıştır. Tüm hipotez kontrolleri 0,05 önem seviyesinde gerçekleştirilmiş, yani $p<0,05$ anlamlı kabul edilmiştir.

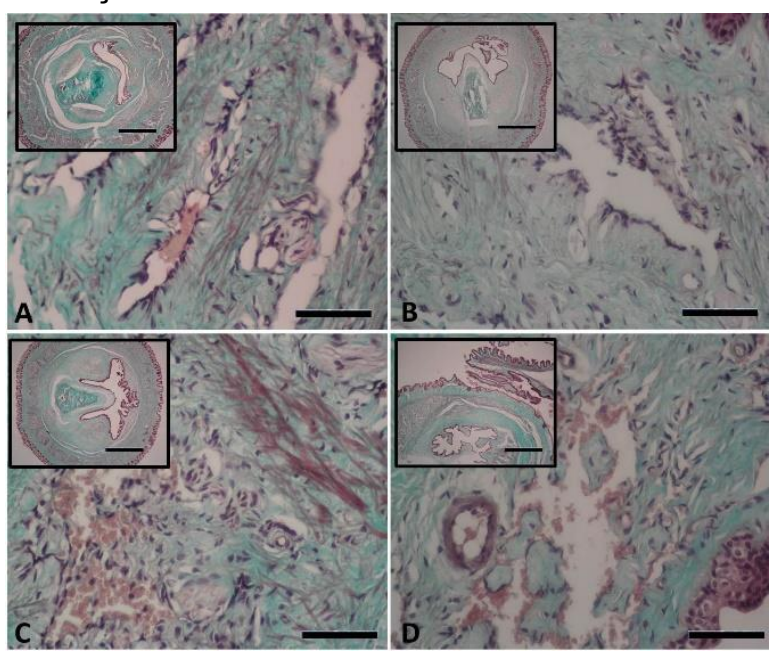

Şekil-2. Deneysel çalışmadaki gruplara ait histopatolojik görüntüler. MT boyama. A. Kontrol grubu. B. Deney grubu. C. Tedavi grubu. D. Plasebo grubu. Küçük fotoğraflar: $x 4$ büyütme (Büyütme barı: $200 \mu \mathrm{m}$ ). Büyük fotoğraflar: x100 büyütme (Büyütme barı $10 \mu \mathrm{m}$ ).

\section{Bulgular}

\section{Histokimyasal Boyama Bulguları}

Kontrol grubu (Grup 1): Penis dokusunun corpus cavernosum denilen iki dorsal erektil doku kitlesi ve içinde üretranın yer aldığı corpus spongiosum'u içerdiği görüldü. Corpus cavernosum'ların merkezi kısmı kollajen ve elastik lifler ile düz kas hücreleri içeren trabeküllerle dolu olduğu saptandı. Trabeküllerin corpus cavernosum'daki, kavernöz boşlukları yapan sinusları çevrelediği görüldü. Trabeküllerde sinir, lenf ve kan damarları bulunduğu saptandı. Sinüzoidler veya kavernöz boşlukların normal histolojik yapıda endotel ile döşeli olduğu saptandı. Elastik liflerin corpus spongiosum'da, corpus cavernosum'u çevreleyen sinüzoidlerin etrafında yerleştiği görüldü. Tunica albuginea'nın iç yüzü ile devamlılık gösteren düz sütunlar veya sinüzoidal trabeküller, fibröz doku, elastik lifler ve düz kaslardan oluştuğu görüldü. İskiokavernöz kas demetleri corpus cavernosum'ların krusları etrafında, bulbokavernöz kas demetleri ise corpus spongiosum'un bulbusu etrafında normal yapıda düz kaslar olarak saptandı (Şekil-2A ve $3 A$ ). Çalışmada kullanılan deney hayvanı sıçan olduğu için hiyalin kıkırdak yapıdaki os penis varlığı saptandı. Mallory trikrom boyalı 
preparatlarda tunica albuginea, fibroelastik trabeküler bağ dokunun yapısı ve düz kas içeriği normal histolojik yapıda gözlendi (Şekil-2A).

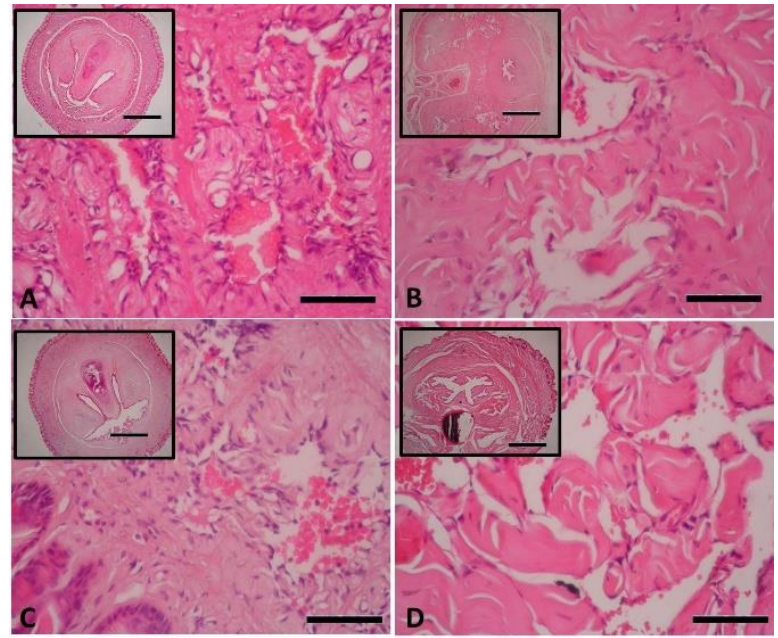

Şekil-3. Deneysel çalışmadaki gruplara ait histopatolojik görüntüler. H\&E boyama. A. Kontrol grubu. B. Deney grubu. C. Tedavi grubu. D. Plasebo grubu. Küçük fotoğraflar: x4 büyütme (Büyütme barı $200 \mu \mathrm{m}$ ). Büyük fotoğraflar: x100 büyütme (Büyütme barı: $10 \mu \mathrm{m}$ ).

Tirotoksikoz modeli oluşturulan grup (Grup 2): Bu gruptaki deneklerde, sinüzoidler veya kavernöz boşlukları döşeyen endotel hücrelerinde kayıp ve kavernöz yapılarda dejenerasyon varlığı saptandı. Tunica albuginea'nın kaba ve dağınık kollajen lif demetleriyle karakterize olduğu görüldü. Fibroelastik bağ doku yapısındaki kavernöz dokuda yaygın fibrotik alanlar dikkat çekici olarak saptandı. Bağ dokusu ve düz kas dağılımı açısından ise tirotoksikoza maruz kalan sıçanlarda elastik lifler ve düz kaslarda belirgin azalma, kollajen liflerde ise artış olduğu saptandı. Fibrozise bağlı olarak kavernöz sinüzoidlerde daralma olduğu görüldü (Şekil-2B ve 3B).

Tirotoksikoz modeli oluşturulan + sildenafil uygulanan grup (Grup 3): Tunica albuginea, corpus cavernosum, venöz sinüsler, kavernozal trabeküler düz kas ve ince fibröz bağ doku normal histolojik yapıya yakın olduğu görüldü. Kırmızı demetler halinde izlenen trabeküler düz kas düzenli görünüm sergilemekteydi. Venöz sinüs endoteli lümene çıkıntı yapan nükleusları ile karakterizeydi. Normal görünümlü endotelle döşeli venöz sinüsler trabeküler bağ dokuyla ayrılmışlardı. Aktif fibroblastlar, düz kas hücreleri ve dağınık halde kollajen lifler içermekteydi (Şekil-2C ve 3C).
Tirotoksikoz modeli oluşturulan + sildenafil taşıyıcı solüsyon uygulanan grup (Grup 4): Masson trikrom boyalı preparatlarda Grup 2'ye benzer görünümde yaygın fibrozis geliştiği saptandı. İnce fibroelastik yapıdaki trabeküler bağ dokusunda kollajen liflerin arttığı ve belirgin biçimde adiposit hücrelerinin birikimi gözlendi. Bunun yanı sıra düz kas hücreleri oldukça azalmış görüldü, hatta düz kas hücre demetlerinin olmadığı kesitler saptandı. Ayrıca kollajen artışına paralel venöz sinüslerde daralma olduğu da belirlendi (Şekil-2D ve 3D).

\section{Immunohistokimyasal Boyama Bulguları}

\section{Anti-eNOS Boyama Bulguları}

Kontrol gruplarına ait preparatlar incelendiğinde kavernöz cisim endotel hücrelerinde immunoekspresyona rastlanmamıştır (Şekil-4A). Tirotoksikoz grubunda kavernöz cisim endotel hücrelerinde orta derece immunoekspresyon saptanmıştır (Şekil-4B). Sildenafil tedavisi alan grupta kavernöz cisim endotel hücrelerinde çok az hücrede immunoekspresyona rastlanmıştır (Şekil-4C). Plasebo grubunda kavernöz cisim endotel hücrelerinde tirotoksikoz grubu benzeri immunoekspresyon saptanmıştır. Fibrotik alanlarda yoğun tutulum görülmüştür (Şekil-4D).

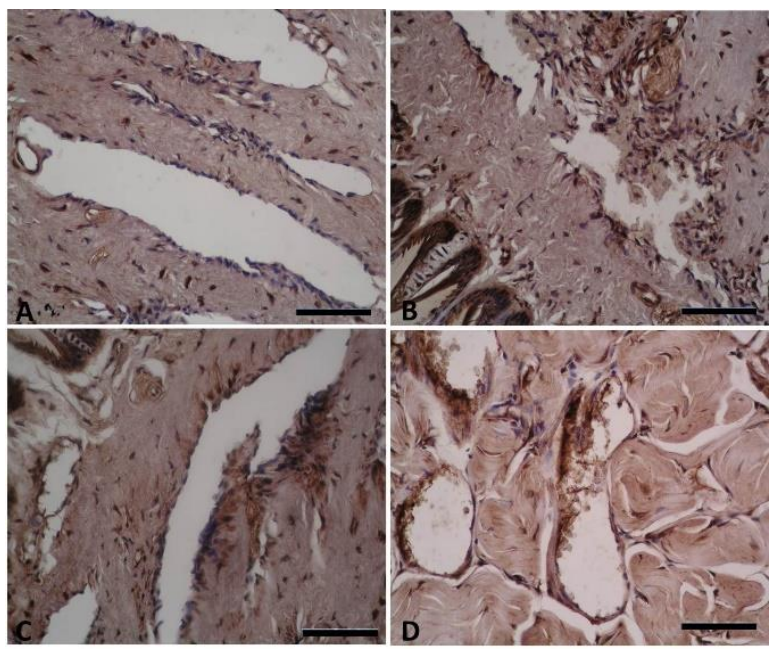

Şekil-4. Deneysel çalışmadaki gruplara ait histopatolojik görüntüler. Anti-eNOS boyama. A. Kontrol grubu. B. Deney grubu. C. Tedavi grubu. D. Plasebo grubu. x100 büyütme (Büyütme barı: $10 \mu \mathrm{m})$.

\section{Anti-iNOS Boyama Bulguları}

Kontrol gruplarına ait preparatlarda kavernöz cisim endotel hücrelerinde immunoekspresyona 
rastlanmamıştır. Endotel komşuluğundaki düz kas hücrelerinde orta derece immunoekspresyon saptanmıştır. Üretra epiteli, kıl kökleri ve penis dışı keratinize olmuş çok katlı yassı epitelde yüksek derece immunoekspresyon saptanmıştır (Şekil-5A). Tirotoksikoz grubunda, kavernöz cisim endotel hücrelerinde immunoekspresyon saptanmıştır. Üretra epiteli, kıl kökleri ve penis dışı keratinize olmuş çok katlı yassı epitelde kontrol grubu ile kıyaslandığında daha düşük dereceli immunoekspresyon mevcuttur. Kavernöz cisim çevresindeki düz kasların azalmasına bağlı olarak bu yapının immunreaksiyonu kontrole kıyasla daha az seviyede gözlenmiştir (Şekil-5B). Tedavi grubunda, kavernöz cisim endotel hücrelerinin çok azında immunoekspresyona rastlanmıştır. Endotele yakın komşulukta bulunan düz kas hücrelerinde kontrole yakın immunoekspresyon saptanmıştır. Üretra epiteli, kıl kökleri ve penis dışı keratinize olmuş çok katı yassı epitelde kontrol grubuna benzer biçimde yüksek derece immunoekspresyon saptanmıştır (Şekil-5C). Plasebo grubunda, kavernöz cisim endotel hücrelerinde tirotoksikoz grubu benzeri immunoekspresyon saptanmıştır. Üretra epiteli, kıl kökleri ve penis dışı keratinize olmuş çok katlı yassı epitelde kontrol grubu ile kıyaslandığında daha düşük dereceli immunoekspresyon saptanmıştır. Kavernöz cisim çevresindeki düz kasların tirotoksikoz grubuna benzer olduğu görülmüştür (Şekil-5D).

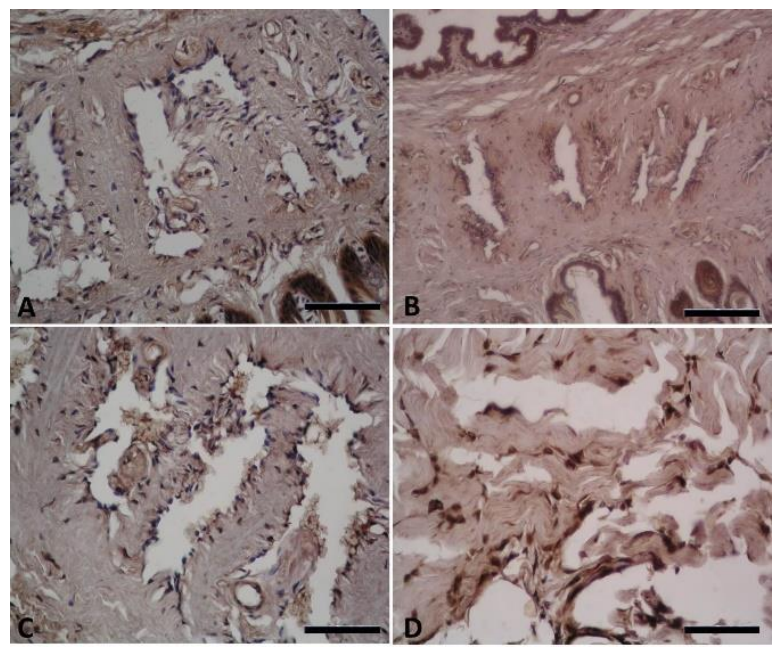

Şekil-5. Deneysel çalışmadaki gruplara ait histopatolojik görüntüler. Anti-iNOS boyama. A. Kontrol grubu. B. Deney grubu. C. Tedavi grubu. D. Plasebo grubu. x100 büyütme (Büyütme barı: $10 \mu \mathrm{m})$.

\section{Anti-VEGF Boyama Bulguları}

Anti-eNOS ve Anti-iNOS boyamalarına benzer şekilde bir dağılım görülmüştür. Kontrol gruplarına ait preparatlar incelendiğinde kavernöz cisim endotel hücrelerinde immunoekspresyona rastlanmamıştır (Şekil-6A). Tirotoksikoz grubunda kavernöz cisim endotel hücrelerinde ve fibrotik alanlarda yoğun tutulum görülmüştür (Şekil-6B). Sildenafil grubunda kavernöz cisim endotel hücrelerinde çok az hücrede immunoekspresyona rastlanmamıştır (Şekil-6C). Plasebo grubunda kavernöz cisim endotel hücrelerinde tirotoksikoz grubu benzeri immunoekspresyon saptanmıştır. Fibrotik alanlarda yoğun tutulum görülmüştür (Şekil-6D).

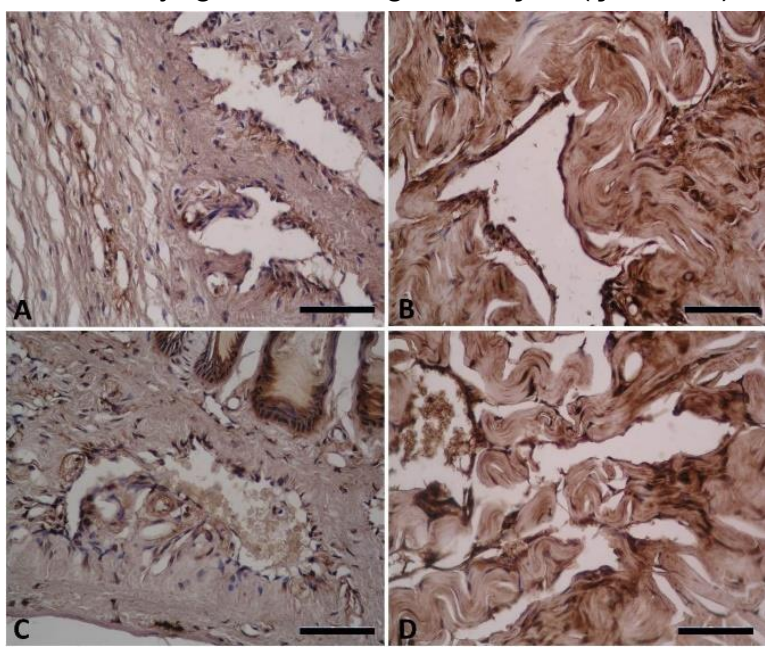

Şekil-6. Deneysel çalışmadaki gruplara ait histopatolojik görüntüler. Anti-VEGF boyama. A. Kontrol grubu. B. Deney grubu. C. Tedavi grubu. D. Plasebo grubu. x100 büyütme (Büyütme barı: $10 \mu \mathrm{m})$.

\section{İstatistiksel Bulgular}

İstatistiksel analiz sonuçları dikkate alındığında, kavernöz damar çapları açısından deney ile placebo grubu arası $(p=1,000)$ farklılık hariç diğer tüm ikili grup farklılıkları istatistiksel olarak anlamlı $\quad(p \leq 0,001)$ bulunmuştur (Şekil-7). Histopatolojik olarak kavernöz yapılardaki fibrozis, dejenerasyon, daralma ve periferik sinir dejenerasyonlarını açısından değerlendirme yapıldığında; fibrozis, dejenerasyon ve daralma sonuçlarında benzer farklılıklar gözlenmiştir. İkili analizlere göre kontrol- tedavi ve deney- plasebo grupları arasındaki farklılıklar istatistiksel olarak anlamlı değilken, diğer tüm ikili farklııklar anlamlı bulunmuştur $\quad(p<0,05)$. Periferik sinir dejenerasyonu açısından ise sadece kontrol 
grubunun deney ve plasebo grubu ile olan farklılıkları anlamlı bulundu $(p<0,05)($ Şekil-8).

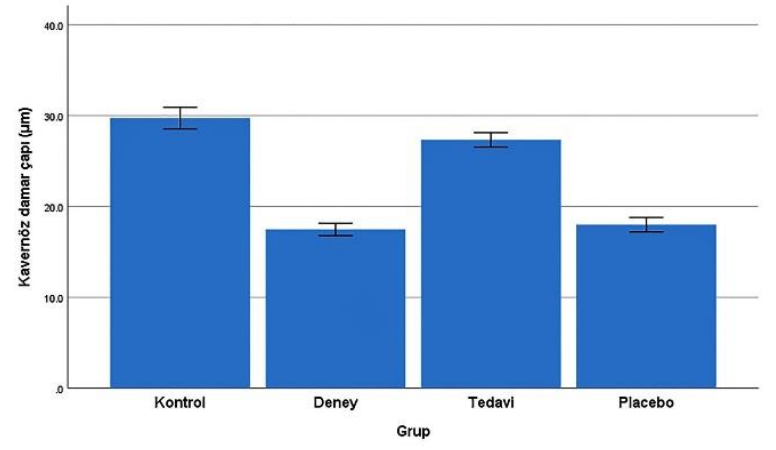

Şekil-7. Kavernöz damar çaplarının istatistiksel olarak değerlendirilmesi. Deney-plasebo grubu arası $(p=1,000)$ farklılık hariç diğer tüm ikili grup farklııkları istatistiksel olarak anlamlıdır $(p \leq 0,001)$.
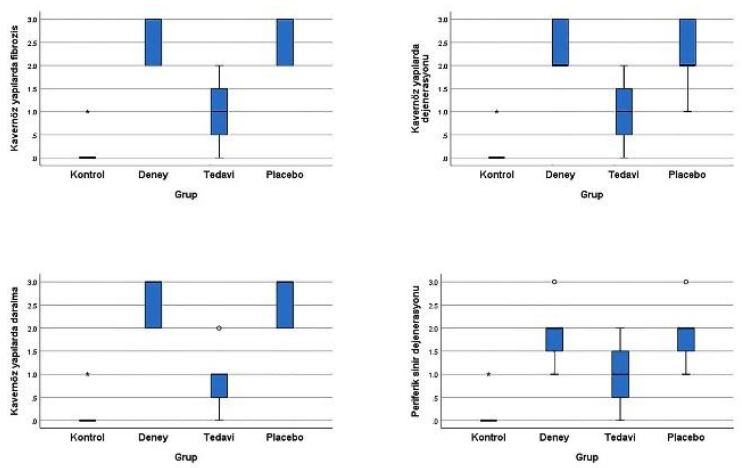

Şekil-8. Kavernöz yapılarda fibrozis, daralma ve dejenerasyon; periferik sinirlerde dejenerasyonun morfometrik analizlerinin istatistiksel olarak değerlendirilmesi. İkili analizlere göre kontrol-tedavi ve deneyplasebo grupları arasındaki farklılıklar istatistiksel olarak anlamlı değilken, diğer tüm ikili farklııklar anlamlı bulunmuştur $(p<0,05)$. Periferik sinir dejenerasyonu açısından ise sadece kontrol grubunun deney ve plasebo grubu ile olan farklııkları anlamlıdır $(p<0,05)$.

\section{Tartışma}

Nitrik oksit (NO) L-arjininden sentezlenir, 1990'ların başlarından itibaren yapısal özelliklerini ortaya koyan çalışmalar yapılmış ve başta kardiyovasküler sistem ve böbrek hastalıkları olmak üzere vücuttaki birçok patofizyolojik mekanizmada önemli rol üstlendiği gösterilmiştir (10). Nitrik oksit bulunduğu bölgedeki derişimi, diğer reaktif oksijen radikallerinin derişimi ve hücre redoks durumuna bağlı olarak antioksidan, düzenleyici veya toksik etki gösterebilmektedir (11). Oksidatif stres hipertiroidizmde patojenik bir faktör olarak kabul edilir. Klinik ve deneysel çalışmalar, artmış serbest oksijen radikali seviyelerini ve tirotoksikozda antioksidan durumunun azaldığını bildirmiştir (12).

Literatür taraması yapıldığında hipertiroidizmin ortaya çıkardığı oksidatif stresi önlemeyi hedefleyen tedavilerin etkinliği üzerine araştırma sayısının oldukça az olduğu görülmüştür. Bu deneysel çalışmada bir PDE-5 inhibitörü olan sildenafilin, tirotoksikozun yol açtığı NO metabolizmasındaki bozulmalara karşı koruyucu etkisini araştırılmıştır.

Hipertiroidi modeli uygulanmış sıçanlarda artan tiroid hormonunun bazı dokularda oksidatif stresi indüklediği gösterilmiştir (13). Makay ve arkadaşları tarafından yapılan L-tiroksin ile indüklenen tirotoksikozlu sıçanlarda oluşan oksidatif stres üzerine melatoninin etkilerinin incelendiği bir çalışmada tirotoksikoz grubunda MDA, GSH ve NO düzeylerinin kontrol ve tedavi gruplarına kıyasla daha yüksek olduğu gösterilmiştir. Tirotoksikoz gruplarında plazmada ölçülen IL-10 ve TNF-alfa düzeyleri de diğer gruplardan yüksek olarak saptanmış, böylece tirotoksikozun oksidatif stres yanıtına yol açtığı ve inflamatuvar sitokin üretimini arttırdığı gösterilmiştir (14).

Corpus cavernosum parankimini esas olarak sinüzoidal alanları çevreleyen düz kas hücreleri ve bu hücreleri destekleyen kollajen lifleri oluşturur. Bu boşluklara ereksiyon sırasında kan dolmasıyla peniste uzama ve sertleşme meydana gelir (15). Ereksiyonun gelişmesi ve sürdürülmesi için bu yapıların normal oran ve yapıda olması gereklidir (16). Nitrik oksit, corpus cavernosum'un kanlanmasını sağlayarak penis ereksiyonunu oluşturabilmektedir. Benzer şekilde oluşturulmuş corpus cavernosum dilatasyonu ve penis ereksiyonu nitrik oksit sentaz (NOS) inhibitörleri tarafından engellenebilir (17).

Nitrik oksitin damar ve stroma hücrelerindeki olduğu gibi düşük derişimlerinden endotelyal nitrik oksit sentaz (eNOS) ile nöronal nitrik oksit sentaz (nNOS) sorumludur ve normal fizyolojik süreçlerin düzenlenmesinde yer alırlar. Indüklenebilir nitrik oksit sentaz (iNOS) ise makrofajlar tarafından aktive edilir. Yüksek NO seviyelerinin görüldüğü sitotoksik etkinin ortaya çıkmasında görev alır (18). Nöronal NOS (nNOS), penil otonom sinirlerde (pelvik pleksus, kavernöz ve dorsal sinirler) ve arteriyollerde bulunurken, endotelyal NOS (eNOS) dorsal 
arterlerin, penil ven ve korporal sinüzoid boşluğun endotel tabakalarında bulunur (19). Nöronal NOS ve eNOS'nin farklı lokalizasyonlarda bulunmaları erektil fonksiyona farklı katkıları olduğu anlamına gelir. Gür ve arkadaşlarının yaptığı çalışmada eNOS ve iNOS protein ekspresyonlarının L-NAME ile hipertansiyon indüklenen sıçanların penil dokularında artığı, ancak eNOS ve iNOS protein ekspresyonunun sildenafil tedavisi ile önemli ölçüde geri kazanıldığını göstermişlerdir. Immunohisto kimyasal analizde kontrol penil dokudaki corpus cavernosum sinirlerinde nNOS boyanmasının L-NAME ve L-NAME+ sildenafil gruplarına kıyasla yoğun olduğu gösterilmiştir. Sildenafil, erektil fonksiyonu geri döndüremese de L-NAME uygulanan edilen sıçanlarda eNOS ifadesini ve cGMP seviyelerini geri kazandırdığını tespit etmişlerdir (20). Ferraz ve arkadaşları yaptıkları çalışmada NOS inhibitörü L-NAME ile kronik uygulamanın erkek sıçanlarda cinsel yanıtı azalttığını göstermiştir. PDE5 inhibitörü sildenafilin birlikte uygulanmasının L-NAME etkilerini azaltması sildenafilin etki mekanizmalarının penil ereksiyonu düzenleyen vasküler mekanizmalarla ilişkilendirilebilir olduğunu düşündürmektedir (21).

Cashen ve arkadaşlarının yaptığı çalışmada eNOS knockout farelerin elektriksel stimülasyona yanıt olarak normal erektil aktiviteye sahip olduğu ve wild tip farelere benzer sildenafil yanıtı gösterdiklerini gözlemlemişlerdir. eNOS'nin incelenen koşullar altında normal erektil fonksiyon için kritik olmadığı ve sildenafilin etkileri için eNOS'nin gerekli olmadığı ileri sürülmüştür. Bu çalışmadaki veriler, nNOS'nin penil NO-cGMP yolunda optimal aktivite ve normal erektil fonksiyon için gerekli olduğunu düşündürmektedir (22).

Carani ve arkadaşları yaptıkları çalışmalarda tiroid disfonksiyonu ve cinsellik arasındaki ilişkiyi inceleyerek hem hipertiroidizm hem de hipotiroidizmin hiposeksüel arzu, erken boşalma, gecikmiş boşalma ve erektil disfonksiyon üzerindeki etkilerini tanımlamayı amaçlamışlardır (4). Erektil disfonksiyon bilinen diğer geleneksel risk faktörlerinden bağımsız olarak, kardiyovasküler ve genel sağlığın önemli bir göstergesidir (23). Erektil disfonksiyon mekanizmaları karmaşıktır. Erektil fonksiyon, corpus cavernosum'da hem nitrerjik sinir lifleri hem de vasküler endotel hücreleri tarafından salınan NO'ya oldukça bağlıdır (24). Cinsel stimülasyona yanıt olarak adrenerjik olmayan, kolinerjik olmayan sinirleri ve kavernozal düz kasların endotel hücreleri, guanilat siklaz tarafından cGMP oluşumunu uyaran, intraselüler $\mathrm{Ca}^{+2}$ seviyesinde ve düz kas gevşemesine neden olan NO salgılar (25). NO-cGMP yolunun normal erektil fonksiyonunun korunmasında rol aldığını gösteren çalışmalar bulunmaktadır $(26,27)$.

Oksidatif stres erektil disfonksiyonun patofizyolojik mekanizmalarındandır. Sıçan penis dokusunda reaktif oksijen türlerinin (ROS) aşırı üretiminin erektil disfonksiyon gelişiminde önemli bir rol oynadığı gösterilmiştir $(28,29)$. Süperoksit anyonu hızla NO'yu inaktive eder, kavernozal düz kasları gevşetme yeteneğini bozar (30). Bai ve arkadaşlarının yaptığı çalışmada diyabetik sıçanlarda oluşturulan erektil disfonksiyon modelinde resveratrol ve sildenafil uygulamasının etkileri incelenmiş, intrakavernöz basınç/ortalama arteriyel basınç oranı ile erektil fonksiyon hesaplanarak tedavi almayan diyabetik sıçanlara kıyasla Resveratrol ve sildenafil uygulamalarının bu oranı anlamlı şekilde yükselttiği gösterilmiştir. ELISA ile ölçülen kavernöz cGMP düzeylerinin de erektil disfonksiyonlu sıçanlara resveratrol ve/veya sildenafil uygulamalarıyla arttığını saptamışlardır. Ancak kavernöz dokulardan western blot ile yapılan nNOS, eNOS ve PDE5 ölçümlerinde tedavi almayan diyabetik grup ile sildenafil grubu arasında anlamlı bir fark gösterilmemiştir (31). Bir diğer çalışmada sildenafilin iNOS ve eNOS ekspresyonunu arttırdığını ve pro-apoptotik protein Bax ile karşılaştırıldığında anti-apoptotik protein $\mathrm{Bcl}-2$ oranını arttırdığını göstermişıerdir. Sildenafilin, iNOS ve eNOS üzerindeki etkileri yoluyla NO ve cGMP seviyelerini arttırdığını varsayarak cGMP'nin parçalanması sildenafil tarafından inhibe edilmesiyle K-ATP kanallarının açılması ve bu sayede kardiyoprotektif etkisinin oluştuğunu düşünmüşlerdir (32).

Fosfodiesteraz tip 5 (PDE5) inhibitörleri düz kas gevşemesini sağladıkları için, corpus kavernosum düz kas üzerindeki etkileri ile penil kan akışını arttırırlar $(33,34)$. Sildenafil sitrat, PDE5 enzimini inhibe ederek hücre içi cGMP'yi artırır. cGMP'ye bağlı protein kinazlar kalsiyum kanallarını inhibe ettiği için hücre içi $\mathrm{Ca}^{+2}$ düzeyleri düşük kalır (35). Medina ve arkadaşları sildenafil sitratın hem hayvan hem de kadavra çalışmalarında penis kan damarlarında gevşeme sağladığını göstermişlerdir. Sildenafil sitrat tedavisinin kan akışını artırarak hem reseptör hem de postreseptör düzeylerinde penis dokusunu hipoksik hasarlardan koruduğu sonucuna varılabilir (36). Ayrıca farklı 
çalışmalarda sildenafil ve vardenafilin uygulandıkları sıçan modellerinde fibrozisi önlediği ve normal düz kas içeriğini korunmasına katkı sağladığı gösterilmiştir $(37,38)$.

Bilateral kavernöz sinir hasarı (BCNI) yapılan sıçanlarda penil atrofi ve erektil disfonksiyon üzerine icariin (azgın teke otu) ve sildenafil etkilerinin araştırıldığı bir çalışmada sham hayvanlara kıyasla bilateral kavernöz sinir hasarı olan sıçanlarda penil kalınlıkta önemli bir azalma gözlenmiştir. Penil interstisyel fibroz, MT boyaması ile kalitatif ve yarı kantitatif olarak değerlendirilerek BCNI'yi takiben, sham ile karşılaştırıldığında düz kas/kollajen oranında önemli bir artışla birlikte fibrozis tespit edilmiştir. Corpus cavernosum'daki düz kas içeriğini incelemek için phalloidin boyaması yapılarak $\mathrm{BCNI}$ grubunda sham grubuna kıyasla düz kas içeriğinde önemli bir azalma olduğu gözlemlenmiştir. Icariin uygulanan hayvanlarda sildenafil ile tedavi edilen hayvanlara göre daha yüksek düz kas içeriğine sahip olma eğiliminde olmalarına rağmen, istatistiksel fark anlamlı bulunmamıştır (39). Özden ve arkadaşlarının yaptığı bir çalışmada da unilateral ve bilateral kavernöz sinir hasarı yapılan sıçanlarda sildenafil tedavisinin penil ağırlık üzerine olumlu etkileri olduğu görülmüş, TUNEL ile düz kaslarda apoptoza giden hücre sayısında bilateral sinir hasarı yapılan grupta artış olduğu ve sildenafil uygulamasının apoptozu önleme yönünde olumlu etkileri olduğu ortaya konmuştur (40).

Endotel, NO üretiminin önemli bir kaynağı olduğu için eNOS ereksiyon sürecinde kritik bir rol oynamaktadır $(41,42)$. Kronik sildenafil uygulaması ile görülen vWF ve eNOS'deki artışlar endotel hücrelerinin korunduğunu düşündürmektedir, bu uygulama NO salınımında ve cGMP düzeylerinde artışlara yol açmaktadır (43). Farklı bir çalışmada ise diyabetin yol açtığı erektil disfonksiyona sahip sıçanlarda pankreatik kininojenaz ve sildenafilin etkileri incelenmiş, diyabet olup tedavi almayan grupta VWF, a-SMA, eNOS ve cGMP düzeylerinin kontrole göre düşük olduğu saptanmıştır. Sildenafil ve/veya pankreatik kininojenaz uygulanan gruplarda bu parametrelerin olumlu şekilde etkilenerek kontrol grubuna yaklaştığı gözlemlenmiştir (44). Endotel hücreleri üzerindeki bu koruyucu etki ile sildenafil uygulaması erektil fonksiyonun geri kazanılmasına katkıda bulunduğu düşünülmektedir.

Bu çalışma kısıtlılı̆ı açısından değerlendirilecek olursa; sıçan ve insan penisleri morfolojik olarak farklıdır, hayvan modelinin kullanımı çalışma için sınırlama bir faktördür. Bununla birlikte, her iki tür de aynı yapısal bileşenlere sahiptir ve bu bileşenlerin farklı deneysel koşullara maruz kaldıklarında benzer şekilde tepki verdiği görülmektedir $(45,46)$.

\section{Sonuç}

Sonuç olarak L-tiroksin uygulaması ile oluşturulan deneysel tirotoksikoz modelinin penil kavernöz dokuda histolojik hasara neden olduğu tespit edilmiştir. Güçlü antioksidan nitelikleri bulunan sildenafil desteğinin dokudaki antioksidan-oksidan dengesini kurma yönünde tirotoksikozun ortaya çıkardığı oksidatif stresin olumsuz etkilerini azaltabileceği histopatolojik olarak görülmüştür. Ayrıca belirli bir dozdaki sildenafil sitrat tedavisinin, erektil fonksiyonda rol oynayan adrenerjik ve kolinerjik sistemler üzerinde koruyucu bir etkiye sahip olup olmadığı konusunda ileri çalışmalara intiyaç duyulmaktadır.

\section{Teşekkür}

İstatistiksel değerlendirmeler konusunda desteği için Ege Üniversitesi Tıp Fakültesi Biyoistatistik ve Tıbbi Bilişim Anabilim Dalı Öğretim Üyesi Doç. Dr. Timur Köse'ye teşekkür ederiz.

Çıkar çatışması: Yazarlar çıkar çatışması beyan etmemişlerdir.

\section{Kaynaklar}

1. Moon JH, Yi KH. The Diagnosis and Management of Hyperthyroidism in Korea: Consensus Report of the Korean Thyroid Association. Endocrinol Metab. 2013; 28 (4): 275.

2. Ross DS, Burch HB, Cooper DS, Greenlee MC, Laurberg P, Maia AL, et al. 2016 American Thyroid Association Guidelines for Diagnosis and Management of Hyperthyroidism and Other Causes of Thyrotoxicosis. Thyroid. 2016 Oct 1; 26 (10): 1343-421.

3. Bahn RS, Burch HB, Cooper DS, Garber JR, Carol Greenlee M, Klein I, et al. Hyperthyroidism and other causes of thyrotoxicosis: Management guidelines of the american thyroid association and American association of clinical endocrinoloigists. Endocr Pract. 2011 May 1; 17 (3): 456-520. 
4. Carani C, Isidori AM, Granata A, Carosa E, Maggi M, Lenzi A, et al. Multicenter study on the prevalence of sexual symptoms in male hypo- and hyperthyroid patients. J Clin Endocrinol Metab. 2005 Dec; 90 (12): 6472-9.

5. Krassas GE, Poppe K, Glinoer D. Thyroid Function and Human Reproductive Health. Endocr Rev. 2010 Oct $1 ; 31$ (5): 702-55.

6. Patel N, Kashanian J. Thyroid Dysfunction and Male Reproductive Physiology. Semin Reprod Med. 2016 Oct 14;34(06):356-60.

7. Gong B, Ma M, Xie W, Yang X, Huang Y, Sun T, et al. Direct comparison of tadalafil with sildenafil for the treatment of erectile dysfunction: a systematic review and meta-analysis. Int Urol Nephrol. 2017 Oct 1; 49 (10): 1731-40.

8. Scaglione F, Donde S, Hassan TA, Jannini EA. Phosphodiesterase Type 5 Inhibitors for the Treatment of Erectile Dysfunction: Pharmacology and Clinical Impact of the Sildenafil Citrate Orodispersible Tablet Formulation. Clin Ther. 2017 Feb 1; 39 (2): 370-7.

9. Makay O, Yenisey C, Icoz G, Genc Simsek N, Ozgen G, Akyildiz M, Yetkin E. The role of allopurinol on oxidative stress in experimental hyperthyroidism. J Endocrinol Invest. 2009 Sep; 32 (8): 641-6.

10. Çekmen, M. B., Turgut, M., Türköz, Y., Aygün, A. D., \& Gözükara, E. M. Nitrik Oksit (NO) ve Nitrik Oksit Sentaz (NOS)'ın Fizyolojik ve Patolojik Özellikleri. Turkiye Klinikleri Journal of Pediatrics, 2001; 10 (4), 226-235.

11. Thomas, D., et al. The chemical biology of nitric oxide: implications in cellular signaling. Free Radical Biology and Medicine, 2008, 45.1: 18-31.

12. Bianchi G, Solaroli E, Zaccheroni V, Grossi G, Bargossi AM, Melchionda N, et al. Oxidative stress and antioxidant metabolites in patients with hyperthyroidism: Effect of treatment. Horm Metab Res. 1999; 31 (11): $620-4$

13. Venditti, P., et al. Effect of thyroid state on lipid peroxidation, antioxidant defences, and susceptibility to oxidative stress in rat tissues. Journal of Endocrinology, 1997, 155: 151-157.

14. Makay, B., et al. The interaction of oxidative stress response with cytokines in the thyrotoxic rat: is there a link?. Mediators of inflammation, 2009, 2009.

15. Goldstein, A. M. B., et al. New observations on microarchitecture of corpora cavernosa in man and possible relationship to mechanism of erection. Urology, 1982, 20.3: 259-266.

16. Costa WS, Carrerete FB, Horta WG, Sampaio FJB. Comparative analysis of the penis corpora cavernosa in controls and patients with erectile dysfunction. BJU Int. 2006 Mar; 97 (3): 567-9.

17. Burnett, A. L., et al. Nitric oxide: a physiologic mediator of penile erection. Science, 1992, 257.5068: 401-403.

18. Bassenge E. Coronary vasomotor responses: Role of endothelium and nitrovasodilators. Cardiovasc Drugs Ther. 1994 Aug; 8 (4): 601-10.

19. Andersson KE, Wagner G. Physiology of penile erection. Physiol Rev. 1995; 75 (1): 191.

20. Gur S, Kadowitz PJ, Gurkan L, Chandra S, Dewitt SY, Harbin A, et al. Chronic inhibition of nitric-oxide synthase induces hypertension and erectile dysfunction in the rat that is not reversed by sildenafil. BJU Int. $2010 \mathrm{Jul} ; 106$ (1): 78-83.

21. Ferraz, M., et al. The effects of sildenafil after chronic L-NAME administration in male rat sexual behavior. Pharmacology Biochemistry and Behavior, 2016, 146: 13-20.

22. Cashen DE, MacIntyre DE, Martin WJ. Effects of sildenafil on erectile activity in mice lacking neuronal or endothelial nitric oxide synthase. Br J Pharmacol. 2002; 136 (5): 693-700.

23. Salonia A, Castagna G, Saccà A, Ferrari M, Capitanio U, Castiglione F, et al. Is Erectile Dysfunction a Reliable Proxy of General Male Health Status? The Case for the International Index of Erectile FunctionErectile Function Domain. J Sex Med. 2012; 9 (10): 2708-15.

24. Rajfer J, Aronson WJ, Dorey FJ, Bush PA, Ignarro LJ. Nitric oxide as a mediator of relaxation of the corpus cavernosum in response to nonadrenergic, noncholinergic neurotransmission. N Engl J Med. 1992 Jan 9; 326 (2): $90-4$.

25. Försterrmann, U., et al. Isoforms of nitric oxide synthase: functions in the cardiovascular system. European heart journal, 1993, 14: 10-15. 
26. Ahn, G. J., et al. Increased expression of the nitric oxide synthase gene and protein in corpus cavernosum by repeated dosing of udenafil in a rat model of chemical diabetogenesis. Asian journal of andrology, 2009, 11.4: 435.

27. Angulo J, González-Corrochano R, Cuevas P, Fernández A, Fuente JML, Rolo F, et al. Diabetes exacerbates the functional deficiency of NO/cGMP pathway associated with erectile dysfunction in human corpus cavernosum and penile arteries. J Sex Med. 2010; 7: 758-68.

28. Tuncayengin A, Biri H, Onaran M, Şen I, Tuncayengin Ö, Polat F, et al. Cavernosal tissue nitrite, nitrate, malondialdehyde and glutathione levels in diabetic and non-diabetic erectile dysfunction. Int J Androl. 2003 Aug; 26 (4): 250-4.

29. Hirata H, Kawamoto K, Kikuno N, Kawakami T, Kawakami K, Saini S, et al. Restoring Erectile Function by Antioxidant Therapy in Diabetic Rats. J Urol. 2009 Nov;182 (5): 2518-25.

30. Shukla N, Rossoni G, Hotston M, Sparatore A, Del Soldato P, Tazzari V, et al. Effect of hydrogen sulphidedonating sildenafil (ACS6) on erectile function and oxidative stress in rabbit isolated corpus cavernosum and in hypertensive rats. BJU Int. 2009 Jun; 103 (11): 1522-9.

31. Bai, Y., \& An, R. Resveratrol and sildenafil synergistically improve diabetes-associated erectile dysfunction in streptozotocin-induced diabetic rats. Life sciences, 2015, 135: 43-48.

32. Han J, Kim N, Joo H, Kim E, Earm YE. ATP-sensitive $\mathrm{K}+$ channel activation by nitric oxide and protein kinase $G$ in rabbit ventricular myocytes. Am J Physiol - Hear Circ Physiol. 2002 Oct; 283 (4 52-4).

33. Zusman, R. M., et al. Overall cardiovascular profile of sildenafil citrate. The American journal of cardiology, 1999, 83.5: 35-44.

34. Vignozzi L, Filippi S, Morelli A, Ambrosini S, Luconi M, Vannelli GB, et al. Effect of chronic tadalafil administration on penile hypoxia induced by cavernous neurotomy in the rat. J Sex Med. 2006; 3 (3): 419-31.

35. Lucas, K. A., et al. Guanylyl cyclases and signaling by cyclic GMP. Pharmacological reviews, 2000, 52.3: 375-414.

36. Medina, P., et al. Effects of sildenafil on human penile blood vessels. Urology, 2000, 56.3: 539-543.

37. Ferrini, M. G., et al. Vardenafil prevents fibrosis and loss of corporal smooth muscle that occurs after bilateral cavernosal nerve resection in the rat. Urology, 2006, 68.2: 429-435.

38. Ferrini, M. G., et al. Long-term continuous treatment with sildenafil ameliorates aging-related erectile dysfunction and the underlying corporal fibrosis in the rat. Biology of reproduction, 2007, 76.5: 915-923.

39. Xu Y, Xin H, Wu Y, Guan R, Lei H, Fu X, et al. Effect of icariin in combination with daily sildenafil on penile atrophy and erectile dysfunction in a rat model of bilateral cavernous nerves injury. Andrology. 2017 May 1; 5 (3): 598-605.

40. Özden E, Öztürk B, Koşan M, et al. Effect of sildenafil citrate on penile weight and physiology of cavernous smooth muscle in a post-radical prostatectomy model of erectile dysfunction in rats. Urology. 2011; 77 (3): 761.e1-761.e7617.

41. De Young LX, Domes T, Lim K Bin, Carson J, Brock GB. Endothelial Rehabilitation: The Impact of Chronic PDE5 Inhibitors on Erectile Function and Protein Alterations in Cavernous Tissue of Diabetic Rats. Eur Urol. 2008 Jul 1; 54 (1): 213-20.

42. Bivalacqua TJ, Champion HC, Usta MF, Cellek S, Chitaley K, Webb RC, et al. RhoA/Rho-kinase suppresses endothelial nitric oxide synthase in the penis: A mechanism for diabetes-associated erectile dysfunction. Proc Natl Acad Sci U S A. 2004 Jun 15; 101 (24): 9121-6.

43. Behr-Roussel, D., et al. Chronic sildenafil improves erectile function and endothelium-dependent cavernosal relaxations in rats: lack of tachyphylaxis. European urology, 2005, 47.1: 87-91.

44. Chen, G., et al. Pancreatic kininogenase improves erectile function in streptozotocin-induced type 2 diabetic rats with erectile dysfunction. Asian journal of andrology, 2018, 20.5: 448.

45. De Souza DB, Silva D, Cortez CM, Costa WS, Sampaio FJB. Effects of Chronic Stress on Penile Corpus Cavernosum of Rats. J Androl. 2012 Jul 1; 33 (4): 735-9.

46. Pinheiro ACAD, Costa WS, Cardoso LEM, Sampaio FJB. Organization and relative content of smooth muscle cells, collagen and elastic fibers in the corpus cavernosum of rat penis. J Urol. 2000; 164: 1802-6. 